\title{
PELESTARIAN AIR BAWAH TANAH DI KOTA MAKASAR
}

\author{
Asriadi Asriadi $^{1)}$, Agung Pamudjianto ${ }^{2)}$ \\ 1), 2) Program Studi Teknik Sipil Universitas Muhammadiyah Sorong \\ Jl Pendidikan No 27 Kota Sorong \\ Email : asriadisoq89@gmail.com
}

\begin{abstract}
Abstraks: Kebutuhan akan air selalu meningkat dengan berkembangnya pembangunan dan berkembangnya jumlah penduduk. Berkembangnya pembangunan baik di kota maupun di desa, akan mengurangi lahan resapan air sehingga jumlah air yang masuk ke dalam tanah untuk mengganti air tanah yang keluar menjadi berkurang. Proses pengendalian pemanfaatan air bawah tanah merupakan upaya untuk menjamin pemanfaatan air bawah tanah secara bijaksana serta menjaga kesinambungan kuantitas dan kualitasnya. Pertumbuhan kebutuhan akan air bersih seiring dengan pertumbuhan jumlah penduduk dan perkembangan aktivitasnya serta keterbatasan sumber air baku air permukaan cenderung mendorong pemanfaatan air tanah yang terus meningkat. Upaya pelestarian air bawah tanah di Kota Makassar telah dilakukan melalui aspek perizinan, aspek pengawasan, aspek penertiban, dan aspek konservasi (rehabilitasi).
\end{abstract}

\section{Pendahuluan:}

Besarnya volume air hujan yang meresap ke dalam tanah akan menentukan tercapai atau tidaknya keseimbangan kondisi air tanah. Keseimbangan atau kelestarian air tanah akan tercapai apabila input air tanah sama dengan output air tanah atau dengan kata lain volume pengambilan air tanah sama dengan volume penambahan debit air tanah.

Pada kenyataan sekarang ini dan perkiraan di masa yang akan datang, keseimbangan air tanah akan terganggu jika penggunaan air tanah dari waktu ke waktu selalu meningkat. Kebutuhan akan air selalu meningkat dengan berkembangnya pembangunan dan berkembangnya jumlah penduduk. Berkembangnya pembangunan baik di kota maupun di desa, akan mengurangi lahan resapan air sehingga jumlah air yang masuk ke dalam tanah untuk mengganti air tanah yang keluar menjadi berkurang. Di lain pihak penggunaan air tanah sebagai sumber air bersih semakin meningkat dengan bertambahnya 
jumlah penduduk. Kondisi ini menyebabkan volume air tanah berkurang menjadi dua kali lipat.

Kota Metropolitan Makassar, ibukota Provinsi Sulawesi Selatan, merupakan pusat pemerintahan dengan berbagai kegiatan sosial, politik, kebudayaan maupun pembangunan. Secara geografis Kota Metropolitan Makassar terletak di pesisir pantai barat Sulawesi Selatan pada koordinat $119^{\circ} 18^{\prime} 27.97^{\prime \prime} 119^{\circ} 32^{\prime} 31.03^{\prime \prime}$ Bujur Timur dan 500'30.18" - 5¹4'6.49" Lintang Selatan dengan luas wilayah sekitar $175.77 \mathrm{~km}^{2}$ (Tjandraatmadja, et al, 2012).

Seiring dengan perkembangan dan kemajuan Kota Makassar yang pesat, Kota Makassar juga mengalami beberapa permasalahan, salah satunya adalah air bersih. Hal ini disebabkan tingginya pertumbuhan penduduk, yang menyebabkan tingkat penggunaan air bersih yang tinggi pula. Selain itu, meningkatnya urbanisasi dan industrialisasi di Kota Makassar memiliki efek negatif pada sumberdaya air pada umumnya dan airtanah pada khususnya. Hal tersebut terkait erat dengan penggunaan airtanah untuk mencukupi kebutuhan hidup dan proses produksi untuk usaha dan industri di Kota Makassar.

Semakin bertambahnya jumlah penduduk dan perkembangan industri menyebabkan bertambahnya kebutuhan akan airtanah yang secara langsung menimbulkan dampak negatif terhadap ketersediaan dan kualitas airtanah diantaranya adalah penurunan muka airtanah, intrusi air laut, dan pencemaran airtanah. Penurunan muka airtanah terjadi karena eksploitasi airtanah secara berlebihan untuk memenuhi kebutuhan hidup, usaha, dan industri, khusus untuk daerah pantai eksploitasi airtanah secara berlebihan selain menimbulkan penurunan muka airtanah juga mengakibatkan intrusi air laut ke dalam airtanah sedangkan pencemaran airtanah timbul dari pembuangan limbah rumah tangga dan industri yang mengabaikan aspek lingkungan. Upaya penanggulangan permasalahan airtanah tersebut sangat diperlukan demi kemakmuran dan kualitas hidup masyarakat yang lebih baik.

Jika potensi air tanah ini dimanfaatkan secara optimal dan berwawasan 
kelestarian sumber daya tersebut, maka diharapkan kebutuhan air bersih masyarakat Kota Makassar akan terpenuhi. Potensi air bawah tanah sangat diharapkan dapat memenuhi kebutuhan masyarakat Kota Makassar akan air bersih karena minimnya potensi air permukaan. Oleh karenanya diperlukan kajian tentang pengendalian pemanfaatan dan pelestarian air bawah tanah di Kota Makassar.

\section{Pembahasan}

Prasarana yang diperlukan dalam penyediaan air bersih meliputi berbagai komponen seperti bangunan pengambilan, saluran/pipa transmisi, instalasi pengolahan air, jaringan pembawa, jaringan distribusi, reservoir dan kelengkapan-kelengkapan lain yang diperlukan untuk mendukung sistem penyediaan air bersih secara optimal. Penentuan jenis prasarana yang diperlukan mempertimbangkan berbagai faktor seperti (Direktorat Cipta Karya PU. 1995) : (1) jenis, letak dan lokasi sumber air, (2) lokasi dan sebaran daerah pelayanan yang mengacu pada scenario pengembangan, (3) keadaan topografi pada sumber air dan daerah pelayanan, (4) sistem pengaliran yang digunakan, (5) kualitas baku.

Akibat dari keadaan geografis yang berbeda, intensitas hujan yang tidak merata, maka ketersediaan air di suatu daerah berbeda dengan di daerah lain. Rata-rata ketersediaan air di suatu daerah dinyatakan dengan Indeks Ketersediaan Air (IKA) yang menyatakan ketersediaan air alami dalam ribuan $\mathrm{m}^{3}$ per orang per tahun. Bahrudin dalam Kodoatie (2002) menyatakan bahwa IKA rata rata di dunia adalah (IKA=7,6), di Asia (IKA=4), di Indonesia $($ IKA $=16,8)$ di Pulau Jawa dengan penduduk yang cukup padat memiliki (IKA =1,6), Papua dan Maluku memiliki $($ IKA $=250)$. Ketersediaan air bagi penduduk menunjukkan indikator daya dukung air bagi lingkungan hidup terutama bagi penduduk dan kegiatannnya. Ketersediaan air permukaan terdiri atas air yang mengalir di permukaan berupa sungai; air yang tertampung di kolam, waduk, danau, maupun rawa; dan air di dalam tanah berupa air tanah. Ketersediaan air 
tersebut tersebar di berbagai pulau di Indonesia dengan kuantitas maupun kualitas yang berbeda (Kodoatie et.al, 2002: 92)

Menurut Dyah, dalam Kodoatie (2002) kebutuhan air terbesar berdasarkan sektor kegiatan dapat dibagi dalam tiga kelompok besar yaitu: Kebutuhan domestik, irigasi pertanian dan industri. Sejalan dengan pertambahan penduduk di Indonesia, maka kebutuhan air akan meningkat pula baik di daerah perkotaan maupun perdesaan.

Sumber daya air adalah merupakan bagian dari sumber daya alam yang mempunyai sifat yang sangat berbeda dengan sumber daya alam lainnya. Air adalah sumber daya yang terbaharui, bersifat dinamis dan mengikuti siklus hidrologi yang secara alamiah berpindah-pindah serta mengalami perubahan bentuk dan sifat. Tergantung dari waktu dan lokasinya, air dapat berupa zat padat, sebagai es dan salju, dapat berupa zat cair yang mengalir sebagai permukan, berada dalam tanah sebagai air tanah, berada di udara sebagai air hujan, berada di laut sebagai air laut dan berupa uap air yang didefinisikan sebagai air udara (Kodoatie et.al, 2002: 27).

Air adalah semua air yang terdapat pada, di atas ataupun di bawah permukaan tanah, termasuk dalam pengertian ini air permukaan, air tanah, air hujan, dan air laut yang berada di darat. Air permukaan adalah semua air yang terdapat pada permukaan tanah. Air tanah adalah air yang terdapat pada lapisan tanah atau batuan di bawah permukaan tanah. (UU No 7 Tentang Sumber Daya Air, 2004). Air tanah juga dapat diartikan sejumlah air di bawah permukaan bumi yang dapat dikumpulkan dengan sumur-sumur, terowongan atau sistem drainase atau dengan pemompaan. Dapat juga disebut aliran yang secara alami mengalir ke permukaan tanah melalui pancaran atau rembesan (Kodoatie dan Sjarief, 2005: 15).

\section{Konservasi Sumber Daya Air}

Masalah lingkungan timbul sebagai akibat timbulnya salah satu dari kondisi-kondisi melampaui kemampuan suatu komponen, adanya 
ketidakseimbangan diantara komponen, terganggunya fungsi komponen atau sama sekali tidak mampu berfungsi seperti biasanya. Masalah selanjutnya ialah rusaknya tata lingkungan alami yang merupakan dampak dari tingkah laku manusia dalam mengeksploitasi dan menggunakan sumber-sumber daya alam secara tidak seimbang (over stress) (Siahaan, 2004: 33). Air merupakan sumber daya alam yang sangat dibutuhkan oleh manusia, kebutuhan akan air meningkat seiring dengan pertumbuhan penduduk. Kebutuhan yang tinggi akan pemanfaatan air perlu diiringi dengan upaya guna pelestarian sumber daya alam tersebut.

Konservasi air dapat diartikan sebagai usaha-usaha untuk meningkatkan jumlah air tanah yang masuk ke dalam tanah dan untuk menciptakan penggunaan air tanah yang efisien, sedangkan konservasi tanah dapat diartikan sebagai tindakan untuk menggunakan tanah berdasarkan kemampuannya dan memperlakukannya sesuai syarat-syarat yang diperlukan agar tanah dapat tetap produktif dan tidak rusak. Konservasi tanah ditujukan tidak hanya untuk mencegah kerusakan tanah akibat erosi dan memperbaiki tanah yang rusak, tetapi juga untuk mengoptimalkan penggunaan tanah dalam jangkah waktu yang tidak terbatas. Salah satu faktor penyebab erosi adalah pukulan air hujan atau aliran permukaan pada permukaan tanah yang terlindungi. Berdasarkan uraian yang singkat di atas maka konservasi tanah merupakan dua hal yang saling terkait.

Konsep konservasi telah mengalami perkembangan dari pemikiran menyimpan air dan menggunakan dikemudian hari atau dikenal dengan konservasi segi suplai berkembang mengarah pada pengurangan atau pengefisien penggunaan air dan dikenal sebagai konservasi sisi kebutuhan. Konservasi air yang baik merupakan gabungan dari dua konsep tersebut yakni menyimpan air dan menggunakannya sesedikit mungkin untuk keperluan tertentu yang produktif (Suripin, 2002). 


\section{Pengendalian Pemanfaatan Ruang}

Pengendalian pemanfaatan Ruang kawasan perkotaan diselenggarakan melalui kegiatan pengawasan dan penertiban pemanfaatan ruang berdasarkan mekanisme perizinan, pemberian insentif dan disinsentif, pemberian kompensasi, mekanisme pelaporan, mekanisme pemantauan, mekanisme evaluasi dan mekanisme pengenaan sanksi (Departemen Kimpraswil Dirjen Penataan Ruang, 2002: V-17).

Menurut Kodoatie (2005: 296) pengendalian pemanfaatan ruang dilakukan melalui kegiatan pengawasan dan penertiban terhadap pemanfaatan ruang, dengan maksud agar pemanfaatan ruang sesuai dengan rencana tata ruang. Dalam prakteknya pengendalian tata ruang merupakan bagian dari penataan ruang (UUPR) yang meliputi Perencanaan (pengarahan), Pemanfaatan (pembangunan) dan Pengendalian (kontrol terhadap pembangunan). Dan Rencana Tata Ruang menjadi dasar bagi pengendalian pemanfaatan ruang di Indonesia.

Pengendalian pemanfaatan ruang dilakukan sebagai upaya untuk mewujudkan tertib ruang. Pengendalian pemanfaatan ruang dilakukan melalui penetapan peraturan zonasi, baik dalam bentuk peraturan pemerintah dalam skala nasional maupun perda dalam skala provinsi, kabupaten/kota. Pengendalian pemanfaatan ruang dapat juga dilakukan melalui upaya perizinan yang diatur oleh pemerintah menurut kewenangan masing-masing. Pemberian insentif dan disinsentif juga merupakan salah satu cara di dalam melakukan pengendalian pemanfaatan ruang, yakni dengan memberikan insentif bagi kawasan yang ingin dikembangkan sedangkan disinsentif diberikan bagi kawasan yang ingin dibatasi perkembangannya. Bagi setiap pemanfaatan ruang yang tidak sesuai aturan (RTR dan peraturan zonasi) dikenakan sanksi. Pemberian sanksi merupakan tindakan penertiban yang juga dilakukan dengan maksud melakukan pengendalian pemanfaatan ruang. 


\section{Pengendalian Pemanfaatan Air Tanah}

Pemanfataan air tanah yang tidak terkendali dapat menyebabkan dampak negatif. Menurut Kodoatie (2005) pengambilan air tanah melalui sumur sumur akan mengakibatkan lengkung penurunan muka air tanah (depression cone). Jika laju pengambilan air tanah dari sejumlah sumur jauh lebih besar dari pengisiannya, maka lengkung-lengkung penurunan muka air tanah antara sumur satu dengan lainnya akan menyebabkan terjadinya penurunan muka air tanah secara permanen. Sedangkan pada daerah pantai, penurunan air tanah dapat menyebabkan intrusi air laut. Pengambilan air tawar yang berlebihan mengakibatkan penurunan muka air tanah tawar dan kenaikan muka air laut sehingga mengakibatkan terjadinya intrusi air laut.

Menurut Kodoatie et.al. (2005) kebijakan yang diambil dalam rangka pengendalian pemanfaatan air tanah antara lain pengaturan persyaratan dalam pemberian izin pengeboran, penurapan mata air dan pengambilan, serta pembatasan debit pengambilan. Kebijakan ini bertujuan mempertahankan kesinambungan keberadaaan air tanah agar mampu menopang kebutuhan untuk jangka panjang dan masa datang. Disebutkan Peraturan Pemerintah tentang air tanah dalam pemanfaatan (penggunaan) air tanah, dilakukan dengan cara:

1. Mengatur kedalaman akuifer yang disadap;

2. Mengatur kedalaman pengeboran atau penggalian air tanah;

3. Mengatur jarak antar sumur bor air tanah;

4. Membatasi debit penggunaan air tanah; dan/atau

5. Membatasi penyadapan air tanah pada akuifer yang sudah rawan dan kritis dengan mengurangi jumlah pengambilan dan penggunaan air tanah.

Pengendalian pemanfaatan air tanah sebagaimana dimaksud pada ayat terutama ditujukan pada:

1. Akuifer yang air tanahnya banyak dieksploitasi;

2. Daerah lepasan air tanah yang mengalami degradasi akibat pengambilan air tanah yang intensif. 


\section{Pelestarian Air Tanah di Makassar}

Pelestarian air tanah di Kota Makssar dilakukan berkaitan dengan konsep perizinan, konsep pengawasan, konsep penertiban dan konsep rehabilitasi yang dideskripsikan kemudian diinterpretasikan.

\section{Konsep Perizinan}

Perizinan air bawah tanah juga perlu dilaksanakan di Kota Makassar karena dengan perizinan dapat menjalankan fungsi pengendalian terhadap pengambilan debit air bawah tanah. Mengingat air merupakan sumber daya yang strategis, sangat penting bagi kebutuhan hidup orang banyak. "Perizinan pemanfaatan air bawah tanah perlu dilakukan karena proses perizinan merupakan fungsi kontrol terhadap pengambilan debit air bawah tanah dan untuk menjaga kelestarian air bawah tanah, air merupakan sumber daya yang strategis dan vital untuk hajat hidup orang banyak untuk itu perlu dilestarikan..." (Kn.piz/PP-2/5-1).

Menurut Departemen ESDM Dirjen Geologi dan SDM (2004: 177) izin selain dimaksudkan sebagai perwujudan aspek legalitas juga ditujukan untuk membatasi pengambilan dan pemanfaatan air tanah melalui ketentuan teknis yang harus dipenuhi oleh pemegang izin, agar pengambilan air tanah sesuai dengan daya dukung ketersediaannya secara alami.

Kegiatan pemanfaatan air bawah tanah dilakukan oleh masyarakat untuk memenuhi kebutuhannya akan air bersih, tetapi dalam pelaksanaannya pengambilan air bawah tanah juga diperjualbelikan (diusahakan), dimanfaatkan untuk mendapatkan penghasilan. Kegiatan ini akan memberikan dampak terhadap kelestarian air bawah tanah jika pengambilannya secara terus menerus dan tidak memperhatikan batasan debit air yang dapat di ambil, atau dengan kata lain kegiatan pengusahaan air bawah tanah perlu dikendalikan.

\section{Konsep Pengawasan}

Pengawasan adalah kegiatan yang dilakukan untuk menjamin tercapainya pelaksanaan teknis dan administrasi pengelolaan air bawah tanah. Menurut 
Departemen ESDM Dirjen Geologi dan SDM (2004: 185, 225) pengawasan perlu dilakukan untuk menjamin ketersediaan air tanah yang berkelanjutan. Pengawasan pengambilan air tanah juga perlu dilakukan untuk mencegah dan menghindari terjadinya dampak negatif akibat pengambilan air tanah yang tidak terkendali.

Pengawasan pemantauan lingkungan hidup dilakukan secara administrasi meliputi kegiatan mengevaluasi laporan pelaksanaan, mengevaluasi laporan hasil analisis kualitas, mengevaluasi laporan kerusakan lingkungan. Pengawasan teknis meliputi kegiatan melaksanakan inspeksi secara berkala, melakukan inspeksi khusus apabila diduga terjadi kerusakan atau pencemaran lingkungan dan melakukan inspeksi teknis peralatan. Dalam pelaksanaannya pengawasan pengelolaan air tanah di Kota Makassar juga menemui kendala, kurang pahamnya masyarakat tentang kelestarian air bawah tanah dan kondisi ekonomi yang sulit menyebabkan masyarakat masih enggan memberikan data pengambilan debit air bawah tanah kepada petugas pengawasan, sekalipun bantuan peralatan untuk mengecek debit air yang terpakai seperti meter ukur telah di sediakan oleh pemerintah.

\section{Konsep Penertiban}

Penertiban adalah upaya penegakkan aturan dalam rangka menjamin terlaksananya pengendalian pengambilan air bawah tanah. Setiap pelanggaran aturan yang terjadi, dikenakan sanksi administrasi dan dikenakan denda dan sanksi pidana penjara. Dalam pelaksanaannya penertiban terhadap pelanggaran aturan pengelolaan air bawah tanah belum dapat diterapkan. Kondisi pengawasan yang belum dapat dilaksanakan dengan optimal, dan sosialisasi peraturan belum dilakukan secara baik menyebabkan pelanggaran yang dilakukan oleh masyarakat belum dapat ditindak lanjuti dengan sanksi sesuai aturan. 


\section{Konsep Konservasi}

Dalam pelaksanaannya upaya koservasi air bawah tanah di Kota Makassar baru meliputi kegiatan penelitian penentuan zona konservasi air bawah tanah yang dilakukan oleh Dinas Pertambangan dan Energi melalui pihak ketiga, upaya mewajibkan pembuatan sumur peresapan melalui IMB yang dan penghijauan atau reboisasi yang bertujuan mengisi kembali debit air bawah tanah guna pelestarian sumber daya air tersebut.

\section{Konsep Pengawasan}

Perizinan air bawah tanah juga perlu dilaksanakan di Kota Makassar karena dengan perizinan dapat menjalankan fungsi pengendalian terhadap pengambilan debit air bawah tanah. Penelitian zona konservasi air bawah tanah sudah menghasilkan daerah yang disarankan sebagai daerah resapan (recharge). Namun hasil penelitian ini belum disosialisasikan dan ditetapkan sehingga dapat dijadikan acuan dalam penentuan daerah resapan di Kota Makassar dengan tujuan mengisi kembali debit air bawah tanah.

Upaya konservasi juga telah dilakukan Pemerintah Kota Makassar melalui Dinas Tata Kota dan Pertamanan Kota Makassar dengan memberikan persyaratan pembangunan sumur resapan pada saat pengurusan Izin Mendirikan Bangunan (IMB). Kewajiban membuat sumur resapan dibuktikan dengan surat pernyataan bersedia membuat sumur resapan oleh pemohon yang diketahui oleh lurah setempat. Namun dalam pelaksanaan pembangunan belum tentu masyarakat dapat patuh melakukan pembangunan sumur resapan mengingat kewajiban membuat sumur resapan ini belum diikuti dengan pengawasan dan penerapan sanksi bagi yang melanggar.

Selain kedua upaya yang disebutkan di atas, upaya konservasi melalui kegiatan reboisasi juga telah dilakukan oleh Pemerintah Kota Makassar, baik berupa kegiatan penghijauan yang dilakukan oleh instansi pemerintah ataupun oleh pemerintah bersama masyarakat. Namun upaya reboisasi ini belum dilakukan dengan memperhatikan daerah resapan air tanah, sehingga upaya 
konservasi yang dilakukan belum bermanfaat bagi kelestarian sumber daya air bawah tanah.

Upaya pemulihan air tanah menurut Kodoatie et.al, (2005) dilakukan untuk memperbaiki atau merehabilitasi kondisi dan lingkungan air tanah yang telah mengalami penurunan kuantitas dan atau kualitas agar lebih baik atau kembali seperti semula. Salah satu cara melakukan pemulihan air tanah adalah dengan melakukan reboisasi hutan.

Kegiatan reboisasi merupakan upaya konservasi yang sudah dilakukanoleh Pemerintah Kota Makassar. Kegiatan reboisasi atau penghijauan ini dilakukan oleh Dinas/instansi atau badan yang berada di dalam lingkup pemerintahan Kota Makassar. Penanaman tanaman dilakukan oleh masingmasing dinas/badan/instansi yang juga bertanggung jawab terhadap pemeliharaannya. Kegiatan konservasi melalui reboisasi belum mempunyai mekanisme yang jelas. Kegiatan reboisasi belum sering dilakukan dan lokasinya belum mempertimbangkan potensi lokasi sebagai daerah resapan air bawah tanah.

\section{Penutup}

Proses pengendalian pemanfaatan air bawah tanah merupakan upaya untuk menjamin pemanfaatan air bawah tanah secara bijaksana serta menjaga kesinambungan kuantitas dan kualitasnya. Demikian pula dengan pengendalian pemanfaatan air bawah tanah di Kota Makassar, pertumbuhan kebutuhan akan air bersih seiring dengan pertumbuhan jumlah penduduk dan perkembangan aktivitasnya serta keterbatasan sumber air baku air permukaan di Kota Makassar cenderung mendorong pemanfaatan air tanah yang terus meningkat bahkan dapat dilakukan secara berlebihan. pengambilan air tanah yang dilakukan secara tidak terkendali dapat mengakibatkan dampak negatif. Upaya pengendalian air bawah tanah di Kota Makassar telah dilakukan melalui aspek perizinan, aspek pengawasan, aspek penertiban, dan aspek konservasi (rehabilitasi). 
Konsep pelestarian air bawah tanah dapat terwujud dengan langkahlangkah sebagai berikut.

a. Sosialisasi aturan perlu dilakukan secara baik, dengan frekuensi yang cukup dan memilih sasaran yang tepat.

b. Melakukan kampanye air guna meningkatkan kepedulian tentang air.

c. Menjadikan prioritas alokasi anggaran terhadap kegiatan pengelolaan air bawah tanah demi terlaksananya kegiatan pengendalian air bawah tanah secara baik.

d. Peningkatan koordinasi antar instansi dalam bidang pengelolaan air bawah tanah berkaitan dengan persyaratan pengurusan persyaratan izin yang dilakukan oleh instansi di luar Dinas Pertambangan dan Energi.

\section{DAFTAR PUSTAKA}

Kodoatie, R.J. 2002. Pengelolaan Sumber Daya Air Dalam Otonomi Daerah. Yogyakarta: Andi Offset.

Kodoatie, J.R. dan R. Syarief, 2005. Pengelolaan Sumber Daya Air Terpadu. Yogyakarta: Andi Offset.

Siahaan.N.H.T. 2004, Hukum Lingkungan dan Ekologi Pembangunan, edisi kedua, Erlangga, Jakarta.

Suripin. 2002. Pelestarian Sumber Daya Tanah dan Air. Yogyakarta: Penerbit Andi.

Tjandraatmadja, G., et al., 2012, Climate Adaptation through Sustainable Urban Development in Makassar, Indonesia -Context and Challenges in Urban Water and Wastewater Services for Makassar, South Sulawesi, Indonesia, CSIRO-AusAID Research Alliance, Australia 